\title{
A RISK ASSESSMENT AUDIT OF THE MANAGEMENT OF ARSENIC ACCUMULATION AND CONSUMPTION IN SOUTH ASIAN RICE
}

\author{
Uma Gunasilan ${ }^{1}$ and Aruna $\mathbf{M}^{2}$ \\ ${ }^{* 1}$ Professor, Hult International Business School, London, United Kingdom. \\ ${ }^{2}$ Assistant Professor, Al Ghurair University, Dubai, United Arab Emirates. \\ *Corresponding Author
}

\begin{abstract}
Rice is the chieffood for about two billion people living in Asia. It has been stated to contain substantial quantity of inorganic arsenic which is noxious to pancreatic beta cells and disturb glucose homeostasis. Millions of consumers around the world may have high Arsenic (As) ingestion from imported rice and rice-based foods, due to the rapid expansion of the global food trade. Arsenic revelation has been linked with enhanced blood glucose and insulin levels, or reduced sensitization of insulin cells to glucose uptake. Arsenic is present in diverse oxidative statuses in the atmosphere and enters in the food chain through soil and water. In the agronomic field, irrigation with arsenic contaminated water, having a greater level of arsenic contamination on the topsoil, affect the quality of crop production. The chief crop like rice (Oryza sativa L.) entails huge amount of water throughout its lifecycle. Rice plants possibly accumulate arsenic, predominantly inorganic arsenic (iAs) from the field, in diverse body parts including grains. Inorganic As varieties are carcinogenic to humans and even at low levels in the diet sham a significant risk to individuals. Extreme accepted daily intake of arsenic accumulated rice $(2.1 \mu \mathrm{g} /$ day $\mathrm{kg}$ body weight $)$ has been fixed by WHO, which may be outdone responsible on its content in rice and amount consumed. Hence, enhanced dominance of diabetes in South Asia may be allied to the ingesting of arsenic contaminated rice. In this work, we have focused on the likely relation between rice consumption, arsenic accumulation, and risk assessment in South Asia.
\end{abstract}

Key words: Rice, Inorganic Arsenic, Accumulation, Risk Assessment, Health Hazards

Cite this Article: Uma Gunasilan and Aruna M, A Risk Assessment Audit of the Management of Arsenic Accumulation and Consumption in South Asian Rice, International Journal of Management (IJM), 12(9), 2021, pp. 1-8.

https://iaeme.com/Home/issue/IJM?Volume=12\&Issue=9 
A Risk Assessment Audit of the Management of Arsenic Accumulation and Consumption in South Asian Rice

\section{INTRODUCTION}

Rice is the chief food for nearly half of the world's population. Rice is the chief food for about two billion people existing in Asia [1]. India, Bangladesh, Pakistan, Afghanistan, Sri Lanka, Nepal, Maldives, and Bhutan are considered as South Asian countries; with the highest population of about 1.2 billion in India and least of about 320,000 in Maldives [2,3]. Asians rice consumptions are comparatively high, although this will depend on the risk of bioaccumulation of arsenic in the body, which is as yet mysterious. Reports revealed higher ranks of arsenic in rice grown in the South. Contamination of rice have disastrous effect.

Arsenic is a fragrance-free and distasteful metalloid element that is found in natural deposits deep in the earth's soil. Several scholars have done research on arsenic levels in rice. Rice appears to soak up larger amounts from ground water than other plants [4]. There are two forms of arsenic found in the environment: inorganic and organic, amongst inorganic arsenic found to be more toxic.

The high toxicity of as is notably present in its inorganic forms. Irrigation with As contaminated groundwater in rice fields increases As concentration in topsoil and its bioavailability for rice crops. It has elevated serious concern from both environmental and human health perceptions. Some South Asian countries like Bangladesh, Nepal and India, arsenic intake from rice diet is pointedly complex, as rice plants have a superior capability to take up arsenic from the soil and water used for irrigation [5,6,7,8,9,10].

United States (US) Environmental Protection Agency (EPA) classified arsenic as a potent human carcinogen and a leading cause of serious health problems, including cancers of the skin, lung, bladder, liver, and kidney, as well as adverse effects on cardiovascular, neurological, hematological, renal, and respiratory systems $[11,12,13]$.

This study considered arsenic health risk to the South Asian residents through oral exposure pathways of rice consumption. This risk assessment exploited data on concentrations of inorganic arsenic in rice grain to estimate exposure to rice consumed alone.

\section{HEALTH HAZARDS}

Arsenic has long been associated with toxic effects, reducing marked impacts on health after both oral and inhalation exposure. Effects range from acute lethality to chronic effects, such as cancer and diseases of the vascular system. Studies in laboratory animals have demonstrated that the toxicity of arsenic is dependent on its form and its oxidation state. It is generally recognized that the soluble inorganic arsenicals are more toxic than the organic ones, and the trivalent forms (AsIII) are more toxic than the pentavalent ones (AsV). There are numerous end-points, with different organ systems being pretentious, comprising the skin and respiratory, cardiovascular, immune, genitourinary, reproductive, gastro-intestinal and nervous systems.

Much of the information about the human health effects of arsenic, in particular in relation to its carcinogenicity, comes from evidence obtained through the study of exposed human populations. Unusually, it has been difficult to find any suitable animal model for the study of arsenic carcinogenicity.

Ingestion of large doses of arsenic usually results in symptoms within 30 to 60 minutes, but may be delayed when taken with food. Acute arsenic poisoning usually starts with a metallic or garlic like taste, burning lips and dysphagia. Violent vomiting may ensue and may eventually lead to hematemesis. These gastrointestinal symptoms are the result of intestinal injury caused by dilatation of splanchnic vessels leading to mucosal vesiculation. These vesicles rupture causing bleeding, diarrhea, and protein wasting. Gastrointestinal symptoms often result in dehydration and electrolyte imbalance and may lead to the development of hypotension and 
hypoxia (Brayer et al., 1997[14]). After the initial gastrointestinal problems, multi-organ failures may occur, followed by death. Survivors of acute arsenic poisoning have been shown to develop hepatomegaly, melanosis, bone marrow suppression, hemolysis, and polyneuropathy resulting from damage to the peripheral nervous system.

Arsenic enters the human body by some pathways such as dermal absorption and oral ingestion via in drinking water. The chronic daily intake (CDI) through oral ingestion and dermal absorption pathways was calculated by the following.

As concentrations, which were used for probabilistic health risk assessments in different age groups of the population. Approximately $43.0 \%$ and $44.4 \%$ of the total as in the grain of polished and husked rice, respectively, was in the form of bio accessible As. Significantly higher bio accessible as concentrations were found in husked rice than in polished rice (1.5-3.8 times greater). The concentrations of bio accessible as in polished and husked rice were lower than the Codex standard for as in rice. The average daily dose of as via rice consumption is equivalent to the daily ingestion of $2 \mathrm{~L}$ of water containing approximately $3.2-7.2 \mu \mathrm{g} \mathrm{L}-1$ of As. Approximately $0.2 \%-13.7 \%$ and $10.7 \%-55.3 \%$ of the population may experience noncarcinogenic effects from polished and husked rice consumption, respectively. Approximately $1 \%-11.6 \%$ of children and $74.1 \%-99.8 \%$ of adults were at risk of cancer. The maximum cancer probabilities were 3 children and 6 adults in 10,000 individuals. The probabilistic risk results indicated that children and adults were at risk of both non-carcinogenic and carcinogenic effects from both types of rice consumption.

\section{ARSENIC ACCUMULATION}

Arsenic (As) speciation in the phloem sap of rice plants and its character in As accumulation in rice grains endure essentially uncharacterized. The total As concentration and As(III) percentage in rice phloem and grain were significantly affected by increasing the phosphate concentration in the medium.

Arsenic is found in nearly all foods and drinks, but is usually only found in small amounts. Rice and rice-based foods: Rice accumulates more arsenic than other food crops. In fact, it is the single biggest food source of inorganic arsenic, which is the more toxic form $[7,8,9,10]$. Arsenic does not usually accumulate (build up) in the body. It leaves the body in different ways: The arsenic that we swallow but that is not absorbed leaves the body in the faeces arsenic is toxic. And it has been associated with lung, skin and bladder cancer, among other health concerns. Inorganic arsenic is the kind that's dangerous and is associated with adverse health effects - and it's the kind that's present in rice.

Long-term exposure to arsenic can increase the risk of cancer of the lungs or bladder. Therefore, it is serious that several rice products on the market contain rather high levels. Compared to other countries, rice from Bangladesh (and India) had the highest percent- age of inorganic As ( 80 percent), against 42 percent in rice from the USA. This indicates that the percentage of inorganic As in rice is not a constant factor geographically and probably depends on cultivar and growth conditions. Table I $[15,16,17]$ provides Mean rice arsenic concentration in white rice from South Asian countries $(\mathrm{mg} / \mathrm{Kg})$.

Current review of Total Arsenic rice in Pakistan was conducted by Pakistan Organic Farms, exporter and supplier of organic rice. 3 sections of organic brown basmati rice containing 500 grams each were obtained from their organic farms in Punjab. Rice samples were categorized based on city of production (Nankana Sahib, Gujranwala and Lahore).

The investigation discovered that rice grown in Punjab had the concentration of Total Arsenic of less than $0.2 \mathrm{mg} / \mathrm{kg}$. Eurofins Global Control, an international inspection company, examined the samples and the results confirms that Pakistan has significantly less Arsenic (mean $0.2 \mathrm{mg} / \mathrm{kg}$ ) than US $(0.714 \mathrm{mg} / \mathrm{kg}$ ). 
The investigation discovered that rice grown in Punjab had the concentration of Total Arsenic of less than $0.2 \mathrm{mg} / \mathrm{kg}$. Eurofins Global Control, an international inspection company, examined the samples and the result confirms that Pakistan has significantly less Arsenic (mean $0.2 \mathrm{mg} / \mathrm{kg})$ than US $(0.714 \mathrm{mg} / \mathrm{kg})$.

An enormous data set (240 samples) for Bangladesh was observed as this country is recognized to have more as contaminated production areas. The mean as concentration in the enormous data set from Bangladesh was considerably greater by a factor of 1.5-2 times associated to the other data sets for Asian rice.

Table 1 Mean rice arsenic concentration in white rice from South Asian countries (mg/Kg)

\begin{tabular}{|c|c|c|c|}
\hline $\begin{array}{c}\text { Country of } \\
\text { origin }\end{array}$ & $\begin{array}{c}\text { Number of } \\
\text { samples } \\
\text { (n) }\end{array}$ & $\begin{array}{c}\text { Mean arsenic } \\
\text { concentration } \\
(\mathrm{mg} / \mathrm{kg})\end{array}$ & $\begin{array}{c}\text { Standard } \\
\text { deviation } \\
(\mathrm{mg} / \mathrm{kg})\end{array}$ \\
\hline \multirow[t]{2}{*}{ India } & 73 & 0.08 & 0.04 \\
\hline & 68 & 0.07 & 0.03 \\
\hline \multirow[t]{2}{*}{ Nepal } & 12 & 0.09 & 0.02 \\
\hline & 12 & 0.06 & 0.03 \\
\hline \multirow[t]{2}{*}{ Bangladesh } & 100 & 0.13 & 0.06 \\
\hline & 240 & 0.23 & 0.11 \\
\hline \multirow[t]{2}{*}{ Pakistan } & 78 & 0.147 & 0.03 \\
\hline & 83 & 0.147 & 0.03 \\
\hline \multirow[t]{2}{*}{ Afghanistan } & 33 & 0.186 & 0.04 \\
\hline & 21 & 0.186 & 0.04 \\
\hline \multirow[t]{2}{*}{ Sri Lanka } & 98 & 0.100 & 0.05 \\
\hline & 121 & 0.100 & 0.05 \\
\hline \multirow[t]{2}{*}{ Maldives } & 34 & 0.06 & 0.03 \\
\hline & 53 & 0.06 & 0.03 \\
\hline \multirow[t]{2}{*}{ Bhutan } & 41 & 0.07 & 0.03 \\
\hline & 26 & 0.07 & 0.03 \\
\hline
\end{tabular}

\section{RISK ASSESSMENT}

The effects of different physio-chemical and biological methods on reduced As levels in rice grains have been extensively investigated over the past decade. For example, alternative water management practices such as intermittent and aerobic irrigation regimes have been found to decrease the availability of $[12,13]$. However, only a limited number of studies have focused on the effects of post-harvesting technologies and cooking methods to decrease As content in raw and cooked rice grains in As endemic areas. Taking this into account, this review article discusses possible causes for high levels of As in cooked rice and potential post-harvesting and cooking techniques to decrease As levels in cooked rice. In addition, in vivo and in vitro methods which are used for evaluating the bio availability and bio accessibility of As species in cooked rice will be discussed. Research gaps and future research directions to reduce as ingestion in humans through cooked rice are also highlighted.

According to the IDF Diabetes Atlas 9th Edition, an estimated 87.6 million adults aged 2079 years were living with diabetes in the South Asia region in 2019, demonstrating a regional frequency of $8.8 \%$. About $56.7 \%$ of these diabetes cases were undiagnosed. Risk Assessment is a practical approach designed to provide decision-makers with valuable information based on the limited data currently available. Hazard identification was described in the above section. Table II delivers rice arsenic consumption per person. 
Table 2 Rice arsenic consumption per person

\begin{tabular}{|l|c|c|}
\hline \multicolumn{1}{|c|}{ Percentile } & $\begin{array}{c}\text { Consumption per } \\
\text { person }(\mathbf{g} / \mathbf{d})\end{array}$ & $\begin{array}{c}\text { Consumption per } \\
\mathbf{k g} \text { body weight } \\
\text { (g/kg/d) }\end{array}$ \\
\hline $\begin{array}{l}\text { Mean } \\
>18 \text { years }\end{array}$ & 23 & 0.3 \\
\hline 4-18 years & 23 & 0.6 \\
\hline 1.5-4.5 years & 14 & 1.0 \\
\hline $\begin{array}{l}\text { 95th percentile } \\
>18 \text { years }\end{array}$ & 76 & 1.0 \\
\hline 4-18 years & 74 & 2.2 \\
\hline $1.5-4.5$ years & 42 & 3.0 \\
\hline $\begin{array}{l}\text { 99th percentile } \\
>18 \text { years }\end{array}$ & 134 & 1.8 \\
\hline 4-18 years & 170 & 3.6 \\
\hline 1.5-4.5 years & 63 & 4.8 \\
\hline
\end{tabular}

Basically, in vitro digestive methods can mimic both enzymatic and physio-chemical processes of the human digestive tract. Studies related to the simulated gastrointestinal digestion (i.e. using artificial gastrointestinal digestion) have shown that inorganic As species in cooked rice were largely bio accessible in humans (63-99\%). There is very limited information available regarding the changes in as speciation in the human digestive system. Human gut microorganisms have previously been found to transform soil-derived As into methylated As species [17, 19].

Table 3 Rice-Intake Data Used in the Risk Assessment

\begin{tabular}{|l|l|l|l|c|}
\hline \multicolumn{1}{|c|}{$\begin{array}{c}\text { Population } \\
\text { Group }\end{array}$} & $\begin{array}{c}\text { NHANES } \\
\text { /WWEIA } \\
\text { Survey Year }\end{array}$ & \multicolumn{1}{|c|}{$\begin{array}{c}\text { Rice Products } \\
\text { Mean }\end{array}$} & $\begin{array}{c}\text { Uncooked } \\
\text { Rice Per } \\
\text { Capita Daily } \\
\text { Intakeb } \mathbf{g} / \mathbf{k g} \\
\mathbf{b w})\end{array}$ & $\begin{array}{c}\text { Mean } \\
\text { Uncooked } \\
\text { Rice Intake } \\
\text { Per Eating } \\
\text { Occasion } \\
\text { (g/kg bw })\end{array}$ \\
\hline$<1$ year & $2003-2010$ & Infant rice cereal & 0.664 & 1.125 \\
\hline$<1$ year & $2003-2010$ & $\begin{array}{l}\text { All rice grain and } \\
\text { products }\end{array}$ & 0.925 & N/Ac \\
\hline $0-6$ years & $2009-2010$ & $\begin{array}{l}\text { All rice grain and } \\
\text { products }\end{array}$ & 0.566 & 1.01 \\
\hline $0-6$ years & $2009-2010$ & $\begin{array}{l}\text { Brown-rice grain } \\
\text { and products }\end{array}$ & 0.046 & 1.929 \\
\hline $0-6$ years & $2009-2010$ & $\begin{array}{l}\text { White-rice grain } \\
\text { and products }\end{array}$ & 0.520 & N/Ac \\
\hline $0-50$ years & $2009-2010$ & $\begin{array}{l}\text { All rice grain and } \\
\text { products }\end{array}$ & 0.332 & 0.866 \\
\hline $0-50$ years & $2009-2010$ & $\begin{array}{l}\text { Brown-rice grain } \\
\text { and products }\end{array}$ & 0.029 & 1.094 \\
\hline $0-50$ years & $2009-2010$ & $\begin{array}{l}\text { White-rice grain } \\
\text { and products }\end{array}$ & 0.303 & \\
\hline
\end{tabular}

Table III conveys Rice-Intake Data Used in the Risk Assessment [18]. The toxic special effects of chronic arsenic exposure have been mainly allied with studies of health effects in adults due, in part, to the restrictions of conducting studies using children as test subjects and, 
in part, due to the complications in measuring developmental deficient endpoints in young subjects. There is proof that augmented cancer in adults may befall as a consequence of acquaintance during childhood. In particular, an ecological study of a Chilean cohort exposed to elevated levels of arsenic over a 12-year period early in life described an increase in lung and bladder cancer that peaked 25 years after the higher acquaintance had clogged.

Maximum lung cancers are owed to cigarette smoking. However, $10-15 \%$ of lung cancers transpire in never-smokers. In accumulation to environmental arsenic exposure, extra identified risk factors for lung cancer comprise exposure to secondhand tobacco smoke, having a family history of lung cancer.

There is a rising body of indication that acquaintance to inorganic arsenic subsidizes to the expansion of many non-cancer adverse health effects and that risk assessments for inorganic arsenic might well include separate assessments for the general population and for susceptible life stages, especially for non-cancer health effects. The NRC (2013) report on inorganic arsenic lists a hierarchy of Health Endpoints of Concern for inorganic arsenic. Fig.1 depicts the Knowledge of cardiovascular disease (CVD) in South Asia. Common participants those suitably branded are heart attack (65\%), angina (59\%) and stroke $(51 \%)$ as types of CVD. Less well renowned CVD events included: heart failure (45\%), peripheral arterial disease (32\%), atherosclerosis (23\%), brain hemorrhage (14\%) and aortic aneurysm (14\%). Additionally, 12\% of participants stated that they did not know what constituted a CVD event or selected 'none'.

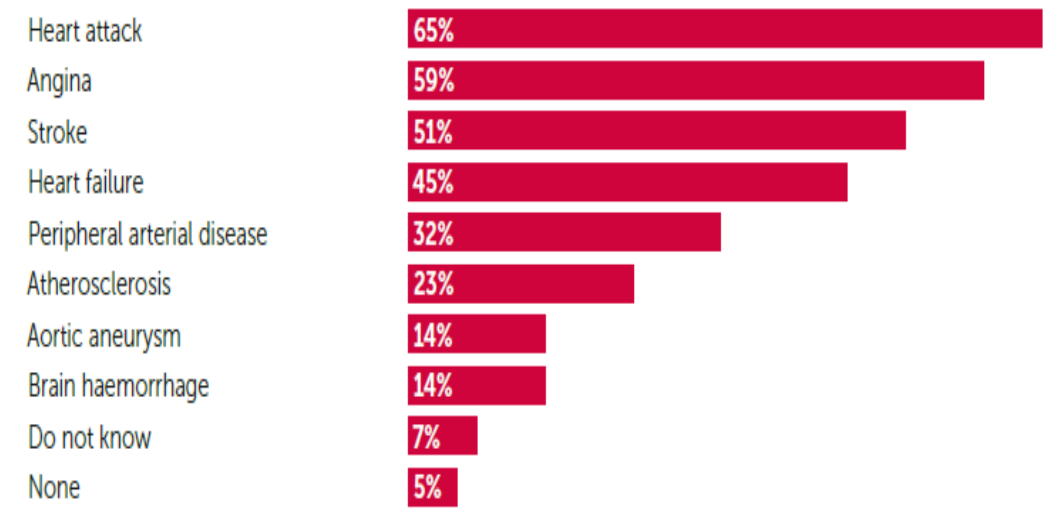

Figure 1 Knowledge of CVD - South Asia.

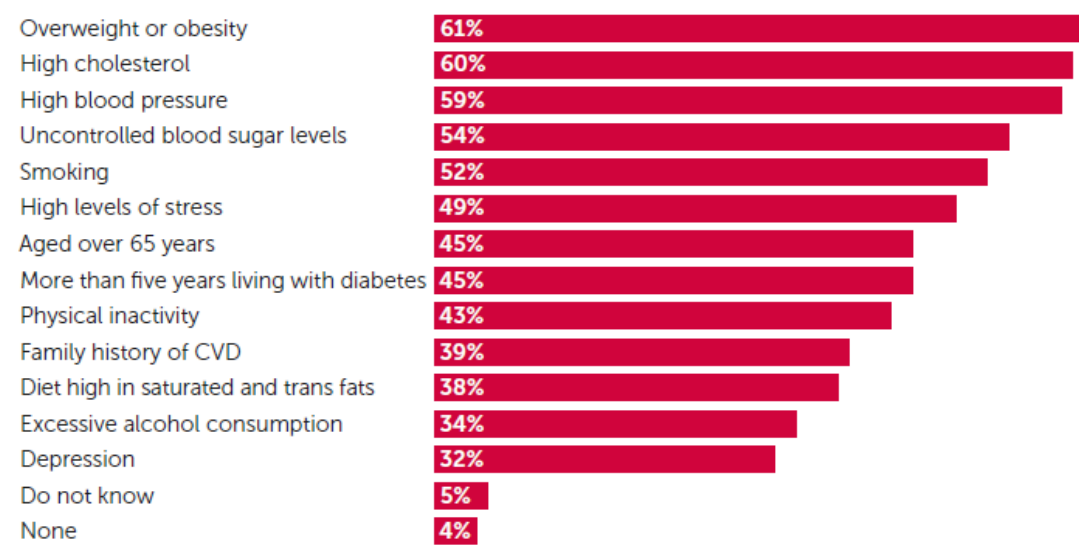

Figure 2 Knowledge of CVD risk factors - South Asia.

Fig. 2 represents the Knowledge of cardiovascular disease (CVD) risk factors in South Asia. The popular correctly identified the following CVD risk factors: being overweight or obese

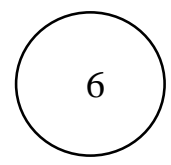


(61\%), high cholesterol (60\%), high blood pressure (59\%), and smoking (52\%). Fewer than half were able to recognise high levels of stress (49\%); being aged 65 or over (45\%); living with diabetes for more than five years (45\%); physical inactivity (43\%); family history of CVD $(39 \%)$; diet containing high amounts of saturated and trans fats $(38 \%)$; excessive alcohol consumption (34\%); or depression (32\%) as risk factors for CVD. Additionally, 9\% of participants stated that they did not know or selected 'none'.

Arsenic has been a stated reason for injury to the pancreatic beta-cells and apoptosis, which in turn alter insulin creation, role and may upshot in insulin dependent diabetes mellitus (IDDM). South Asian countries appear to have a great occurrence of diabetes owing to their deceptive tendency for the disease and life style. It has been reported twice as high in the urban areas, exclusively in India. Brown rice is supposed to encompass $80 \%$ more inorganic arsenic than white rice, because of the existence of germ layer in brown rice. Arsenic endorsement by rice from contaminated underground water or soil has been exposed to increase the exposure risk and especially Diabetes.

\section{CONCLUSION}

Very limited studies have investigated the effects of storage conditions (i.e. storage time and storage temperature) on As content in rice grains. However, there is no conclusive evidence that storage temperature and storage time can influence the as concentration in rice grains. Thus, further investigations are required to confirm whether storage conditions affect as concentrations in rice grains. In addition, it is worth studying the possible changes in as speciation in rice grains under varying storage conditions. Both positive and negative effects of washing of rice can be attributed to as concentrations in water and raw rice grains, the number of washing steps, and sample sizes. Washing time and mode of washing (i.e. mechanical or manual) may also influence the As content of washed rice grains. Further studies are needed to examine the effects of washing time and mode of washing on as content of washed rice grains.

Overall, the inclusion of additional data confirms the conclusions from our market-basket survey that as concentrations in rice from the U.S., Spain, and Italy are not significantly different, and that they are significantly higher than rice from Asia. Risk assessment can provide decision-makers with beneficial quantifiable evidence on demanding topics. Further enhancement of the scientific basis is imperative to ensure that public health will be dwindling, especially for vulnerable residents such as infants and toddlers. Extreme endured everyday consumption of arsenic contaminated rice $(2.1 \mu \mathrm{g} /$ day $\mathrm{kg}$ body weight) has been set by WHO, which may be surpassed liable on its content in rice and amount consumed. Hence, increased predominance of diabetes in South Asia reported.

It would be of great significance to determine if the factors associated with rice consumption behavior, cooking practices, knowledge of arsenic and perception associated with exposure to arsenic in rice observed in our study are representative in populations in other countries. Besides, determining the difference in risk perception between countries, where there are recommendations or regulation limiting acceptable arsenic concentration in rice such as in Europe, with countries where high arsenic in rice prevails, and such regulations are not enacted such as in South and Southeast Asia will be of importance.

\section{REFERENCES}

[1] K. Baldwin, N. Childs, J. Dyck, and J. Hansen, Southeast Asia's rice surplus. Washington DC: US Department of Agriculture, 2012.

[2] R.D. Kaplan, South Asia's geography of conflict. Washington, DC: Center for a New American Security, 2010. 
A Risk Assessment Audit of the Management of Arsenic Accumulation and Consumption in South Asian Rice

[3] K.A. Kohei, Pathophysiology of type 2 diabetes and its treatment policy. JMAJ. 2010, 53:4146.

[4] Mohammad Azizur Rahman, Ataur Rahman, Mohammad Zaved Kaiser Khan, Andre Renzaho, Human health risks and socio-economic perspectives of arsenic exposure in Bangladesh, A scoping review, Ecotoxicology and Environmental Safety 150, 335-343, May 2018

[5] Uptake kinetics of arsenic species in rice plants, Plant Physiol.2002 128 1120-1128.

[6] J. Environ, Bioavailability and uptake of arsenic by wetland vegetation: Effects on plant growth and nutrition. Sci. Health 1998 (33) 45-66.

[7] Arsenic toxicity in crop plants: Physiological effects and tolerance mechanisms, Environ. Chem. Lett 2011 (9) 303-321.

[8] Remediation of Arsenic for Agriculture Sustainability, Food Security and Health in Bangladesh; FAO, Google Scholar, 2007.

[9] J. Bulg, Oxidative changes and photosynthesis in Oat plants grown in As- contaminated soil, Plant Physiol, 2003 (29) 87-95, Google Scholar.

[10] Differential response of oxidative stress and thiol metabolism in contrasting rice genotypes for arsenic tolerance, Ecotoxicol. Environ. Saf 2012 (79) 189-198.

[11] F.A., A biochar application protects rice pollen from high-temperature stress, Plant Physiol. Biochem.2015 96 281-287.

[12] S. Fahad, S. Hussain, S. Saud, S. Hassan, B.S. Chauhan, F. Khan, Responses of Rapid Viscoanalyzer Profile and Other Rice Grain Qualities to Exogenously Applied Plant Growth Regulators under High Day and High Night Temperatures. 2016, PLoS ONE 11(7): e0159590.

[13] Arsenic uptake, accumulation and toxicity in rice plants: Possible remedies for its detoxification: A review, Environ. Sci. Pollut. Res 2017 (24) 9142-9158.

[14] A.F. Brayer, C.M. Callahan, P.M. Wax, Acute arsenic poisoning from ingestion of "snakes". Pediatric Emergency Care, 1997, 13(6): 394-396.

[15] US EPA, Risk assessment guidance for superfund volume I: human health evaluation manual (part E). 2004, http://www.epa.gov/oswer/risk assessment/ragse/pdf/introduction.pdf. Accessed 10 September 2016

[16] Z. Karim, Risk assessment of dissolved trace metals in drinking water of Karachi, Pakistan. Bull Environ Contam. Toxicol., 2011, v.86, pp.676-678. DOI 10.1007/s00128-011-0261-8.

[17] B. Wu, D.Y. Zhao, H.Y. Jia, Y. Zhang, X. X. Zhang, S.P. Cheng, Preliminary risk assessment of trace metal pollution in surface water from Yangtze River in Nanjing Section, China. Bull Environ Contam Toxicol. 2009, v.82, pp.405-409.

[18] Arsenic in Rice and Rice Products Risk Assessment Report, Center for Food Safety and Applied Nutrition, Food and Drug Administration, U.S. Department of Health and Human Services, 2016. 